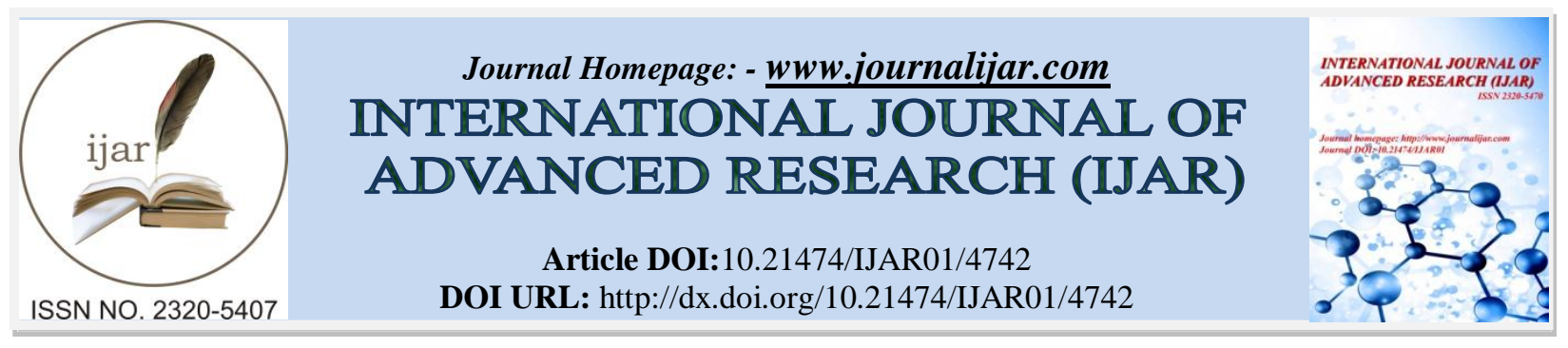

RESEARCH ARTICLE

\title{
SCIENTIFIC EVALUATION OF CERTAIN TRADITIONAL KNOWLEDGE (TK) BASED ORGANIC MANURE FOR THE MANAGEMENT OF PEST AND PATHOGENS OF RICE.
}

Santosh Thoudam and Chhetry G. K. N.

Manipur University, Department of Life sciences, Canchipur, Manipur, India- 795003.

\section{Manuscript Info}

Manuscript History

Received: 5 May 2017

Final Accepted: 7 June 2017

Published: July 2017

\section{Keywords:-}

Traditional knowledge, Rice, Blast, Brown spot, Scirpophaga incertulas, Nymphuladepunctalis,

Colocasiaesculenta.

\section{Abstract}

The experiment was carried out in a rice field located at Mayang Imphal under Imphal West district of Manipur, during June-July for two consecutive years (2011 and 2012) and pest and disease parameters were recorded. During the experiment, treatments used for each plot $\left(4 \mathrm{~m}^{2}\right)$ with a spacing of $20 \times 15 \mathrm{~cm}$ includes 3 green manure levels (2.5 tons/ha, 5 tons/ha and 7.5 tons/ha of Colocasiaesculenta Linn., 3 decomposed cow dung manure levels ( 2.5 tons/ha, 5 tons/ha and 7.5 tons/ha) and a control check (100-40-30kgNPK/ha). The results of this experiment indicated that the population of stem borer and case worm on the chemical fertilizer treatments exhibited the severe outbreak more than in the treatments of green manure crops and decomposed cow dung manure. Also, the disease incidence of blast and brown spot was also reduced in the respective plots as compared to the control check. The experimental results suggest that certain traditional knowledge based organic manure are quite effective in controlling the menace of pests and diseases of rice crops.

Copy Right, IJAR, 2016,. All rights reserved.

\section{Introduction:-}

Traditional knowledge or indigenous traditional/technical knowledge (ITK) is the knowledge possessed by the indigenous people or the ethnic groups or communities around the world.Though the knowledge covers various aspects of life such as healthcare, education, natural resource management etc., (Warren 1991), the information on traditional agriculture pertinent to the management of pest and pathogens of rice crop diseases has never been recorded or documented in a form easily accessible to the farmers and scientists working in the field. This has provided ample scope for the use of ITKs evolved over generations.Management of rice crops in general and pest and disease management approaches in particular are different among indigenous farmers practicing traditional farming systems in different regions of the world because of difference in indigenous knowledge they accrued over generations of their close contact with the nature. Chhetry et al., (2009) reported that there is a resurgence of interest in recent years in reviving the age old farming system through scientific evaluation, which is known by modern man as organic farming, because of hazardous effect of excessive use of chemical fertilizers and over all ill effects of chemical based products to human health etc., in agricultural system. Kannan (1995) reported that Basmati variety of paddy grown during rabi season (January to April) purely on organic basis with liberal quantities of farm yard manure, green leaf manure and neem cake forming the bulk of the basic application gave a more pronounced result in terms of yield and lesser incidence of pest and disease parameters. 
Organic farming is based on enhancing the natural biological cycles in soil, crop and livestock. It involves a wide range of soil management and cropping practices that maintain the balance of the ecosystem and foster ecosystem services (Altieri 1986, 1999, van Bruggen and Semenov 2000).

The experiment was therefore initiated on some selected TKs possessed by the progressive farmers, so as to address the immediate and long-term measures against the two fungal pathogens (Pyricularia grisea, causing blast disease and Drechslera oryzae, causing brown leaf spot of rice)and two other insect pest of economic importance (yellow stem borer and case worm). And as there is a vast scope of scientific exploration of traditional knowledge of farming communities on different aspects of plant health management, investigation about the traditional knowledge possessed by the farmers for the successful management of pest and pathogens of rice in Manipur valley were carried out.

\section{Materials and Methods:-}

As the traditional progressive farmers have been using various organic matters in the form of manure for better yield and also to manage the pests and pathogens of rice crops, an experiment was designed using decomposed cow dung manure and green leaf manure to check their efficacy against pest and pathogens of rice. The experiment was conducted in a rice field located at Mayang Imphal under Imphal West district of Manipur, during June-July for two consecutive years (2011 and 2012) and pest and disease parameters were recorded.

\section{Mode of Preparation of Cow Dung Manure:-}

One year old decomposed cow dung was procured from the locality in bulk a week before the preparation of field and stored in shade area and latter applied in the field. This practice of making soil amendments were commonly used by the local farmers since time immemorial. This practice of amending the soil organically is permitted under organic agriculture system (Yadav, 2007).

\section{Experimental Design:-}

A randomized complete block design was set up with three replications. Each treatment, having plot size of $4 \mathrm{~m}^{2}$ and spacing of $20 \times 15 \mathrm{~cm}$, includes (i) 3 green manure levels $(2.5$ tons/ha, 5 tons/ha and 7.5 tons/ha of Colocasia esculenta Linn., and (ii) 3 decomposed cow dung manure levels (2.5 tons/ha, 5 tons/ha and 7.5 tons/ha) and a control check (100-40-30kgNPK/ha).

Small ridges were established between plots with different treatments to avoid the influences of nutrition from neighbor plots. The sixty day old green manure crop was freshly chopped into pieces and incorporated during the preparation of soil. 35days old seedlings of rice variety $R C M-9$ were transplanted after 10days of soil mixed with different treatments. All management practices were done in proper time starting from land preparation to crop harvest.

The data on severity of blast and brown leaf spot were recorded using the standard visual 0 to 9 ratings scale following the $5^{\text {th }}$ edition of Standard Evaluation System for Rice (IRRI 2013). The disease parameters were worked out using the formulas as given below:

i) Percent disease incidence,

$$
\text { DI }(\%)=\frac{\text { Totalno.oftillersinfectedbyaparticulardisease }}{\text { Totalno.oftillersassessed }} \times 100
$$

ii) Percent disease severity,

$$
\text { DS }(\%)=\frac{\text { Sumofallnumericalratings }}{\text { No.ofleavesobservedxMaximumdiseaseratingscalei.e.,0-9}} \times 100
$$

\section{Pest Assessment:-}

\section{Stem borer:-}

Counts were taken on number of dead hearts/white ears head and total number of tillers/panicle from 10 randomly selected hills. The per cent death heart (DH) and percent white ear head (WH) were calculated as follows,

$$
\begin{aligned}
& \% \mathrm{DH}=\frac{\text { No.ofDH } / \text { Plant }}{\text { Totalno.oftillers } / \text { Plant }} \times 100 \\
& \% \mathrm{WH}=\frac{\text { No.ofWH } / \text { Plant }}{\text { Totalno.oftillers } / \text { plant }} \times 100
\end{aligned}
$$




\section{Case worm:-}

The leaf damage (LD) intensities of caseworm were assessed by random sampling of 20 hills from each plot of different treatments as mentioned above at fortnightly intervals. The percent damaged leaves were calculated as follows,

$$
\% \mathrm{LD}=\frac{\text { LD no./ Plant }}{\text { Total leaves /Plant }} \times 100
$$

\section{Statistical Analysis:-}

An analysis of variance (ANOVA) was performed using Microsoft Excel and the difference between the treatment were separated using least significance difference (LSD) test at $5 \%$ probability level (i.e., $\mathrm{P}=0.05$ )

\section{Results:-}

The population of stem borer and case worm on the chemical fertilizer treatments exhibited the severe outbreak more than in the treatments of green manure crops and decomposed cow dung manure. The population of stem borer and case worm show lesser incidence of $5.27 \%$ and $5.44 \%$ respectively in a plot treated with green manure crop at a dose of 5 tons/ha followed by $6.97 \%$ and $6.79 \%$ at a dose of 2.5 tons/ha of the green manure level (Table 1). Similarly, the lowest incidence of stem borer $(4.2 \%)$ and case worm $(8.73 \%)$ was recorded from the plots treated with cow dung manure at a dose of 5 tons/ha followed by $6.05 \%$ and $12.84 \%$ at a dose 2.5 tons/ha as compared to control check (Table 2).

On the other hand the disease incidence of blast and brown spot was also reduced in the respective plots as compared to the control check. The most tolerant reaction for blast $(2.40 \%)$ and brown leaf spot disease $(3.37 \%)$ respectively were seen in the plots treated with green manure crop at a dose of 7.5 tons/ha, followed by $2.64 \%$ and $3.58 \%$ at a dose of 5 tons/ha as compared to control check (Table 3). On the contrary, lowest incidence of blast $(2.47 \%)$ and brown leaf spot $(9.42 \%)$ respectively were recorded in the plots treated with cow dung manure at a dose of 5 tons/ha, followed by $4.75 \%$ and $12.94 \%$ at a dose of 7.5 tons/ha as compared to the control check (Table 4).

Table 1:- Effect of green manure crop on the incidence of insect pests (stem borer and case worm) of rice crop (RCM-9)

\begin{tabular}{|c|c|c|}
\hline Green manure level & Stem borer & Case worm \\
\hline 2.5 tons/ha & $6.97 \mathrm{c}$ & $6.79 \mathrm{c}$ \\
\hline 5 tons/ha & $5.27 \mathrm{~d}$ & $5.44 \mathrm{~d}$ \\
\hline 7.5 tons/ha & $9.02 \mathrm{~b}$ & $8.97 \mathrm{~b}$ \\
\hline $100-40-30 \mathrm{kgNPK} / \mathrm{ha}$ & $9.94 \mathrm{a}$ & $11.35 \mathrm{a}$ \\
\hline LSD & 0.83 & 0.87 \\
\hline
\end{tabular}

Means within columns followed by different letters are significantly different $(\mathrm{P}=0.05)$

Table 2:- Effect of decomposed cow dung manure on the incidence of insect pests (Stem borer and case worm) of rice crop $(R C M-9)$

\begin{tabular}{|c|c|c|}
\hline $\begin{array}{c}\text { Decomposed cow dung manure } \\
\text { level }\end{array}$ & $\begin{array}{c}\text { Stem borer } \\
\text { DH/WH }\end{array}$ & Case worm \\
\hline 2.5 tons/ha & $6.05 \mathrm{c}$ & $12.84 \mathrm{c}$ \\
\hline 5 tons/ha & $4.2 \mathrm{~d}$ & $8.73 \mathrm{~d}$ \\
\hline 7.5 tons/ha & $7.45 \mathrm{~b}$ & $16.19 \mathrm{~b}$ \\
\hline $100-40-30 \mathrm{kgNPK} / \mathrm{ha}$ & $8.94 \mathrm{a}$ & $20.04 \mathrm{a}$ \\
\hline LSD & 0.93 & 2.97 \\
\hline
\end{tabular}

Means within columns followed by different letters are significantly different $(\mathrm{P}=0.05)$

Table 3:- Effect of green manure on the incidence of blast and brown leaf spot diseases in rice crop (RCM-9)

\begin{tabular}{|c|c|c|}
\hline Green manure level & Blast (\%) & Brown leaf spot (\%) \\
\hline 2.5 tons/ha & $3.05 \mathrm{~b}$ & $5.37 \mathrm{~b}$ \\
\hline 5 tons/ha & $2.64 \mathrm{bc}$ & $3.58 \mathrm{c}$ \\
\hline 7.5 tons/ha & $2.40 \mathrm{c}$ & $3.37 \mathrm{c}$ \\
\hline $100-40-30 \mathrm{KgNPK} / \mathrm{ha}$ & $4.33 \mathrm{a}$ & $7.12 \mathrm{a}$ \\
\hline
\end{tabular}




\begin{tabular}{|c|c|c|}
\hline LSD & 0.62 & 0.56 \\
\hline \multicolumn{3}{|c|}{ Means within columns followed by different letters are significantly different $(\mathrm{P}=0.05)$. } \\
\hline \multicolumn{3}{|c|}{ Table 4:- Effect of cow dung manure on the incidence of blast and brown leaf spot } \\
\hline $\begin{array}{c}\text { Decomposed cow dung manure } \\
\text { level }\end{array}$ & Blast $(\%)$ & Brown leaf spot $(\%)$ \\
\hline 2.5 tons/ha & $3.21 \mathrm{c}$ & $11.02 \mathrm{c}$ \\
\hline 5 tons/ha & $2.47 \mathrm{c}$ & $9.42 \mathrm{~d}$ \\
\hline 7.5 tons $/ \mathrm{ha}$ & $4.75 b$ & $12.94 \mathrm{~b}$ \\
\hline 100-40-30KgNPK/ha & $5.44 \mathrm{a}$ & $16.46 \mathrm{a}$ \\
\hline LSD & 0.63 & 0.52 \\
\hline
\end{tabular}

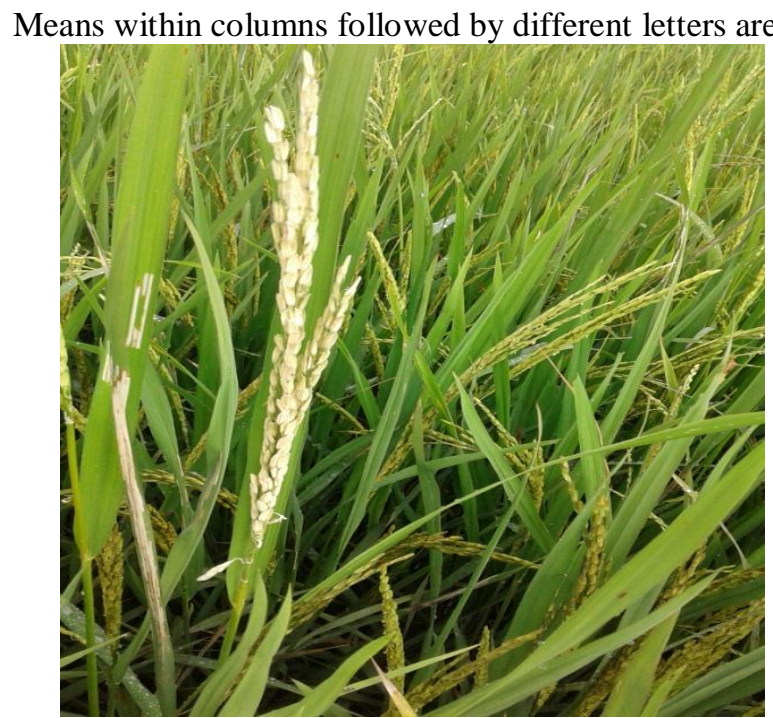

Fig.1:- White ear head

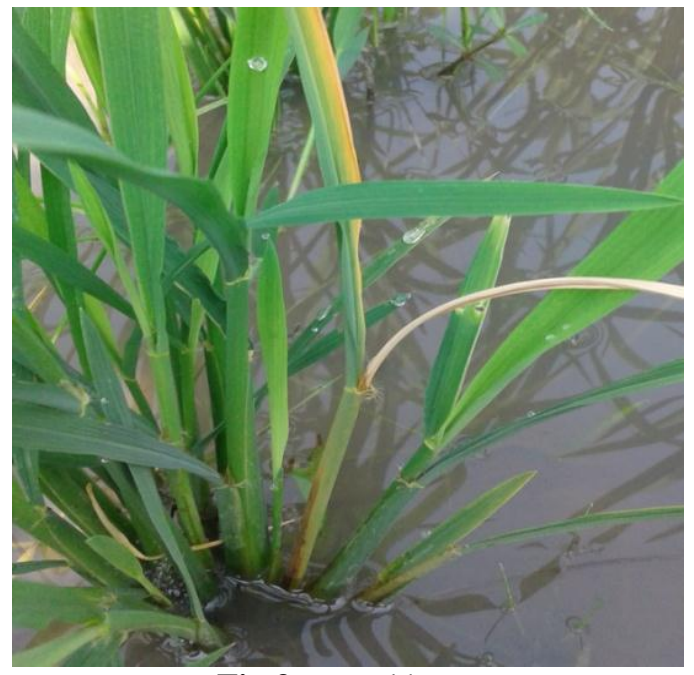

Fig.3:- Dead heart

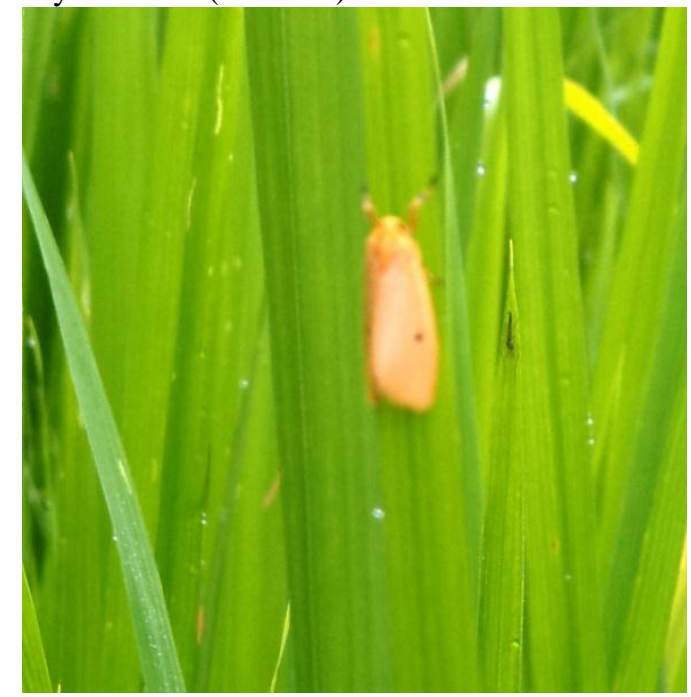

Fig. 2:- yellow stem borer

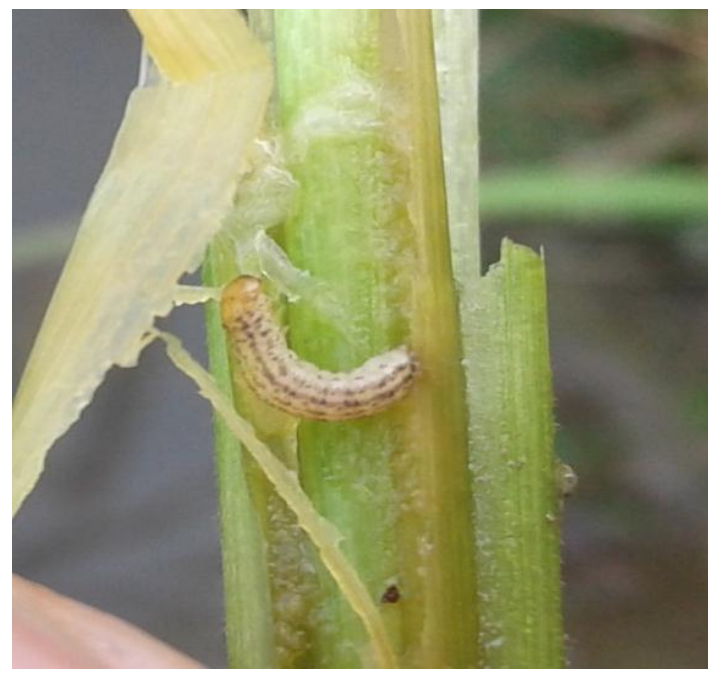

Fig. 4:- Yellow stem borer larva 


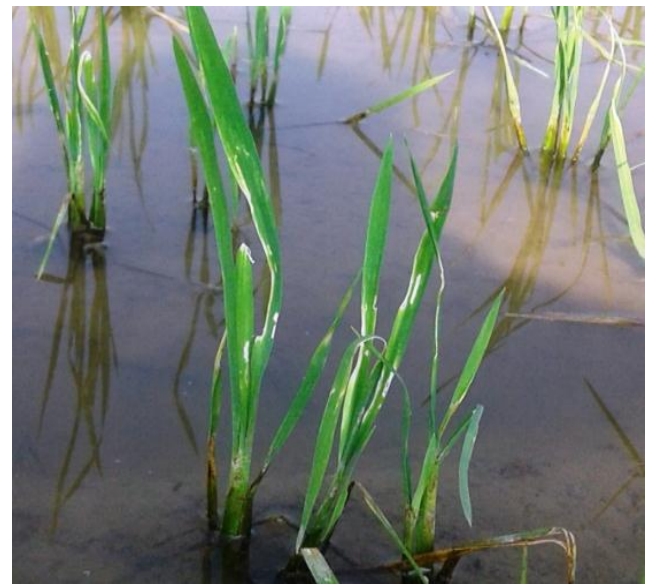

Fig. 5:- Papery epidermis on rice leaf caused by case worm

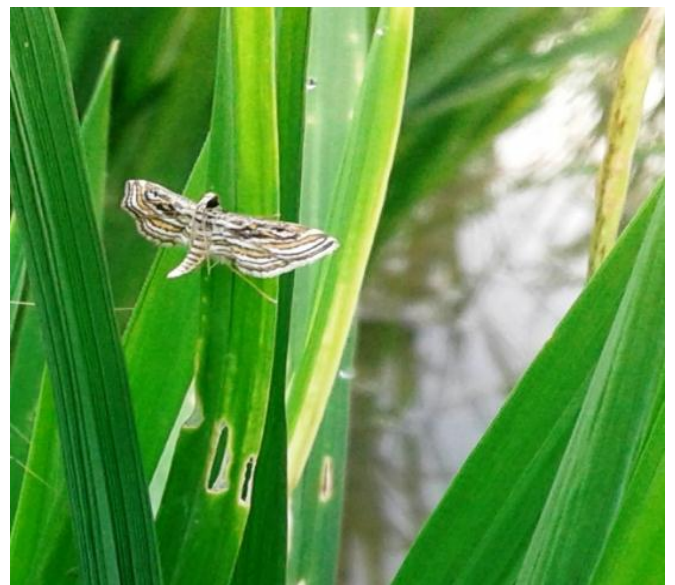

Fig. 6:- Rice case worm (Nymphuladepunctalis)

\section{Discussion:-}

Luonget al., (2005) reported that the population of insect pests as stem borer, brown plant hopper and leaf folder on the chemical fertilizer treatment exhibited the severe outbreak more than in the treatments of chicken and hog manure compost and organic fertilizer application. According to Prasad et al. (2004), leaf folder (Cnaphalocrocismedinalis) and yellow stem borer (Scirpophagaincertulas) were greatest at $200 \mathrm{~kg} \mathrm{~N} \cdot \mathrm{hm}{ }^{-2}$ and lowest at $0 \mathrm{~kg} \mathrm{~N} \cdot \mathrm{hm}^{-2}$. They have also reported that the disease index of blast and sheath blight was reduced $50-60 \%$ and $90 \%$ respectively in the plots treated with chicken and hog manure compost as compared to the chemical fertilizer. The result revealed that green manure crop and decomposed cow dung manure were more effective than chemical fertilizer to induce tolerance to insect pests and diseases. Their effect exhibited through decreasing population and incidence of blast, brown spot, stem borer and as well as case worm of rice. Magdoffet al.,(2000) indicated that farming practices that cause nutrition imbalances can lower pest resistance. The interaction between manure compost, green manure crop and fertilizer was not significant. Similar results were also reported by Gattaniet al., (1976). From the experiment, it can be concluded that most pest and disease control measures used by the farmers should be based on soil fertility management as the capacity of the plants to resist to insect pests and diseases strictly relates to optimal physical, chemical and mainly biological characteristics of the soil.

\section{Acknowledgement:-}

The authors are greatly indebted to resource poor farmers, the Manipur University for granting the University Fellowship and all those who contributed to the success of this study.

\section{References:-}

1. Altieri, M.A. 1999. The ecological role of biodiversity in agro-ecosystems. Agriculture, Ecosystems. Agriculture, Ecosystems \& Environment. 74(1-3): 19-31.

2. Chhetry, G.K.N. and Lassaad Belbahri (2009). Indigenous pest and disease management practices in traditional farming systems in north east India. A review.Journal of Plant Breeding and Crop Science. 1(3): 28-38.

3. Gattani, P. D., Jain, S. V. and Seth, S. P.(1976). Effect of continuous use of chemical fertilizers and manures on soil physical and chemical properties. J.Indian Soc. Soil Sci., 24: $284-289$.

4. IRRI (2013). "Standard Evaluation System for Rice". 5th Edition, International Rice Research Institute, Manila, p. 19-20.

5. Kannan (1995), "Organically grown Basmati Rice", The Hindu, May 31. pp.15.

6. Luong Minh Chau and K.L Heong. (2005). Effects of organic fertilizers on insect pest and diseases of rice. Omonrice.13:26-33.

7. Magdoff, F H Van Es. (2000). Building soils for better crops. SARE, Washington DC. pp.38-44.

8. Prasad, B.R., Raju, N.B.T., Pasalu, I.C. and Babu, T.R. (2004). Influence of nitrogen and rice varieties on insect population build-up and extent of damage. Annals of Plant Protection Sci., 12(1): 217-218.

9. vanBruggen, A.H.C. and Semenov, A.M. (2000). In search of biological indicators for soil health. Applied Soil Ecology. 15 (1): 13-24.

10. Yadav, A.K. (2007), Certification and inspection System in organic Farming System in India, Bulletin of National Centre of Organic Farming. pp.52-64. 